\title{
Pengaruh Karakteristik Ibu dan Kinerja Kader Posyandu Terhadap Partisipasi Ibu Dalam Penimbangan Balita di Posyandu Desa Kedak Kecamatan Semen Kabupaten Kediri
}

\author{
Reny Nugraheni, Dianti Ias Oktaviasari \\ IIK Bhakti Wiyata Kediri \\ Corresponding author: Reny Nugraheni (reny.nugraha.rn@gmail.com) \\ Received: December, 16 2019; Accepted: January, 19 2020; Published: March, 162020
}

\begin{abstract}
ABSTRAK
Banyak program kesehatan yang diadakan pemerintah untuk meningkatkan kesehatan masyarakat, salah satu upaya efektif adalah pemberdayaan masyarakat. Tujuan dari penelitian ini adalah untuk menganalisis pengaruh pengetahuan ibu, pekerjaan ibu, dan kinerja kader posyandu. Jenis penelitian ini adalah cross sectional. Penelitian ini dilakukan dengan pendekatan kuantitatif. Populasi dalam penelitian ini adalah Ibu yang mempunyai balita sebanyak $56 \mathrm{ibu}$ dan 16 kader posyandu. Pengambilan sampel dalam penelitian ini dengan menggunakan teknik Total Sampling. Berdasarkan hasil uji statistik multivariate dengan menggunakan regresi linear berganda didapatkan nilai $\mathrm{p}$-value $=0,001<0,05$, yang artinya ada pengaruh antara karakteristik ibu dan kinerja kader terhadap partisipasi ibu dalam penimbangan balita di Posyandu. Untuk menjadi masukan dan dapat dijadikan bahan penyuluhan ke masyarakat khususnya ibu yang bekerja sehingga kunjungannya ibu balita ke posyandu meningkat dan meningkatkan kinerja kader posyandu dalam menginformasikan jadwal posyandu dan peningkatan partisipasi ibu dalam posyandu melalui kegiatan rutin di lingkungan desa.
\end{abstract}

Kata Kunci: Kinerja Kader, Partisipasi ibu, Penimbangan Balita, Posyandu

This is an open-acces article distributed under the terms of the Creative Commons Attribution-ShareAlike 4.0 International License.

\section{PENDAHULUAN}

Posyandu di Indonesia merupakan salah satu bentuk upaya kesehatan yang strategis serta ber-fungsi sebagai media promosi mau-pun sarana pemantauan pertumbuhan bayi dan balita, kegiatan posyandu diharapkan dapat mendeteksi kasus gizi buruk secara dini di masyarakat sehingga tidak berkembang menjadi kejadian luar biasa. Angka balita yang ditimbang dalam posyandu dapat menjadi indikator keaktifan masyarkat dalam ikut serta posyandu. Maka keaktifan ibu dalam menimbang bayi di Posyandu menjadi salah satu perhatian utama pemerintah, karena agar dapat memantau tumbuh dan kembang balita.

Keaktifan kegiatan dalam Posyandu ini sangat bergantung pada keaktifan dari kinerja kader tersebut Kinerja kader Posyandu dipengaruhi oleh banyak faktor, baik faktor eksternal kader Posyandu maupun faktor internal kader Posyandu. Persentase kader aktif secara nasional yaitu $69,2 \%$ dan angka drop out kader yaitu $30,8 \%$. 
Puskesmas Semen di Kecamatan Semen Kabupaten Kediri, bertanggung jawab pada 12 Desa dengan jumlah kader Posyandu 5 orang di masing-masing desa. Berdasarkan wawancara pendahuluan mengenai pelaksanaan kegiatan Posyandu bulan Desember 2015, jumlah kader Posyandu yang ter-daftar 65 orang untuk 12 desa dan jumlah kader yang aktif hanya 35 orang, ini berarti ada separuh dari jumlah kader yang terdaftar yang tidak aktif dan pada bulan Januari 2016 jumlah kader di Desa Kedak Kecamatan Semen Kabupaten Kediri terdaftar 16 orang untuk 4 posyandu.

Data Riset Kesehatan Dasar (Riskesdas) pada tahun 2013 menyatakan, yaitu ada 19,6\% balita mengalami kekurangan. Serta data tentang pemantauan tumbuh kembang anak yang diperoleh dari frekuensi penimbangan anak balita di posyandu selama enam bulan terakhir frekuensi penimbangan > 4 kali sedikit menurun pada tahun 2013 yaitu $(44,6 \%)$ dibanding tahun 2007 (45,4\%). Dan dalam enam bulan terakhir Anak umur 6-59 bulan yang tidak pernah ditimbang meningkat dari 25,5\% (2007) menjadi 34,3\% (2013). Pada anak sampai usia lima tahun seharusnya dibawa ke Posyandu setiap bulan.

Berdasarkan data dari Dinas Kesehatan Kabupaten Kediri pada tahun 2015, tingkat partisipasi ibu dalam penimbangan di Posyandu (D/S) Pada tahun 2011 sebesar 75,3\%, tahun 2012 sebesar 76,4\%, tahun 2013 sebesar 77,75\%, tahun 2014 sebesar 78,5\%, dan tahun 2015 sebesar 78,65 walaupun mengalami peningkatan, tetapi masih dibawah target $80 \%$. Berdasarkan data laporan tahunan di wilayah kerja 37 Puskesmas dan beberapa Pustu. Terdapat 6 puskesmas perawatan dan 31 non perawatan, juga telah terdapat 4 puskesmas Pelayanan Obstetri Neonatus Essensial Dasar (PONED) di Kabupaten Kediri tahun 2015, angka cakupan D/S yang paling rendah terdapat di Wilayah Kerja Puskesmas Semen yaitu dari jumlah 2.169 balita yang melakukan penimbangan yaitu 1.501 balita. Jadi persentase (\%) D/S di Wilayah Kerja Puskesmas Semen yaitu 69,19\%, artinya angka ini masih jauh dibawah target Dinas Kesehatan Kabupaten Kediri yaitu 80\%.

Berdasarkan data SKDN balita yang absen di posyandu Kedak I di bulan Desember tahun 2015 ada 11 balita, bulan Januari 10 balita dan bulan Februari 8 balita dan ditemukan hasil penimbangan dibawah garis normal ada 3 balita dan gizi lebih ada 1 balita, sedangkan di posyandu Bungas Kedak II balita yang absen di bulan Desember 2015 ada 10 balita, bulan Januari 10 balita dan bulan Februari 9 balita, sedangkan di posyandu Nangka Kedak III di bulan Desember 2015 ada 22 balita, bulan januari 21 balita dan bulan februari 19, sedangkan di posyandu Anggur Kedak IV yang absen di bulan Desember 2015 ada 18 balita, bulan januari 18 dan bulan februari 5 balita dan tidak ditemukan balita gizi kurang.

Berdasarkan penjelasan di atas peneliti ingin mengetahui pengaruh karakteristik ibu dan kinerja kader terhadap partisipasi ibu dalam penimbangan balita di posyandu Desa Kedak Kecamatan Semen Kabupaten Kediri.

\section{METODE}

Desain penelitian ini meggunakan metode penelitian survei analitik, non eksperimen. Jenis penelitian ini adalah cross sectional. Populasi dalam penelitian ini adalah Ibu yang mempunyai balita di Desa Kedak Kecamatan Semen Kabupaten Kediri sebanyak 56 ibu yang mempunyai balita ke posyandu dan 16 Kader Posyandu. Sampel dalam penelitian ini adalah Ibu yang mempunyai balita di Desa Kedak Kecamatan Semen Kabupaten Kediri dan 16 Kader Posyandu. Pengambilan sampel dalam penelitian ini menggunakan teknik Total Sampling artinya sampel yang digunakan merupakan total populasi, sebesar 56 Ibu balita dan 16 Kader Posyandu. 


\section{HASIL PENELITIAN}

Dari hasil uji statistik spearman rank didapatkan nilai Sig (2-tailed) $0,0001<0,05$ (dengan derajat kemaknaan $5 \%$ ), maka $\mathrm{H}_{0}$ ditolak atau variabel pengetahuan ibu terhadap partisipasi ibu memiliki pengaruh dalam pengetahuan ibu terhadap partisipasi ibu dalam penimbangan balita di Posyandu Desa Kedak Kecamatan Semen Kabupaten Kediri dengan arah korelasi positif dan nilai korelasi sedang.

Dari hasil uji statistik spearman rank didapatkan nilai Sig (2-tailed) $0,010<0,05$ (dengan derajat kemaknaan 5\%), maka $\mathrm{H}_{0}$ ditolak atau variabel pekerjaan ibu terhadap partisipasi ibu memiliki pengaruh dalam pekerjaan ibu terhadap partisipasi ibu dalam keaktifan ke posyandu di Desa Kedak Kecamatan Semen Kabupaten Kediri dengan arah korelasi positif dan nilai korelasi lemah.

Dari hasil uji statistik spearman rank didapatkan nilai Sig (2-tailed) $0,004<0,05$ (dengan derajat kemaknaan $5 \%$ ), maka $\mathrm{H}_{0}$ ditolak atau variabel kinerja kader terhadap partisipasi ibu dalam penimbangan balita memiliki pengaruh di Posyandu Desa Kedak Kecamatan Semen Kabupaten Kediri dengan arah korelasi positif dan nilai korelasi kuat.

Dari hasil uji statistik spearman rank didapatkan nilai Sig (2-tailed) 0,008 $<0,05$ (dengan derajat kemaknaan 5\%), maka $\mathrm{H}_{0}$ ditolak atau variabel kinerja kader terhadap partisipasi ibu dalam mengajak penimbangan balita memiliki pengaruh di Posyandu Desa Kedak Kecamatan Semen Kabupaten Kediri dengan arah korelasi positif dan nilai korelasi lemah. Berdasarkan yang berpengaruh adalah partisipasi ibu dalam melaksa nakan penimbangan balita di Posyandu Desa Kedak Kecamatan Semen Kabupaten Kediri.

Berdasarkan hasil uji statistik multivariate dengan menggunakan regresi linear berganda didapatkan nilai Sig (2-tailed) $=0,001<0,05$ (dengan derajat kemaknaan 5\%), maka $\mathrm{H}_{0}$ ditolak sig $<£(0,05)$ ada pengaruh antara karakteristik ibu dan kinerja kader terhadap partisipasi ibu dalam penimbangan balita di Posyandu Desa Kedak Kecamatan Semen Kabupaten Kediri.

\section{PEMBAHASAN}

Dari hasil uji statistik multivariate dengan menggunakan regresi linear berganda didapatkan nilai Sig $\left(2\right.$-tailed) $=0,001<0,05$ (dengan derajat kemaknaan 5\%), maka $\mathrm{H}_{0}$ ditolak $\mathrm{H}_{1}$ diterima artinya ada pengaruh antara karakteristik ibu dan kinerja kader terhadap partisipasi ibu dalam pelaksanaan penimbangan balita di Posyandu Desa Kedak Kecamatan Semen Kabupaten Kediri.

Hasil penelitian yang diperoleh terdapat pengaruh antara karak-teristik (pengetahuan ibu dan pekerjaan ibu) dan kinerja kader terhadap partisipasi ibu dalam penimbangan balita di Posyandu. Dengan demikian semakin baik karakteristik ibu dan kinerja kader maka semakin baik pula partisipasi ibu untuk melakukan kunjungan dalam posyandu balita. ${ }^{9}$ Menyatakan bahwa cakupan penimbangan balita di posyandu dipeng aruhi oleh faktor internal ibu balita (karakteristik ibu) antara lain pekerjaan ibu, status pekerjaan ibu, jumlah anggota keluarga, dan pengetahuan ibu mengenai posyandu. Beberapa cara yang dapat diimplementasikan untuk meningkatkan pengetahuan kader tentang posyandu adalah dengan melakukan pembinaan dan refreshing kader secara berkesinambungan setiap 6 bulan sekali, dengan topik sekurang-kurangnya 5 program posyandu, antara lain yaitu kesehatan ibu dan anak, keluarga berencana, imunisasi, gizi, serta pencegahan dan penang gulangan diare. Penghargaan perlu diberikan pada kader yang berprestasi dan aktif, misalnya dengan pemberian piagam penghargaan yang bertujuan meningkat-kan motivasi kader dalam kegiatan posyandu.Kinerja kader dalam ke-giatan posyandu sebaiknya ditinjau ulang setiap tahun. 


\section{KESIMPULAN}

Pengetahuan ibu di Desa Kedak Kecamatan Semen Kabupaten Kediri, sebesar 76,8\% cukup dan kategori pekerjaan ibu adalah sebesar 75.0\% Ibu Rumah Tangga. Kinerja kader dalam pelaksanaan penimbangan balita sebesar $87.5 \%$ kategori Baik dan kader posyandu dalam mengajak ibu-ibu untuk datang pada hari kegiatan posyandu oleh kader posyandu di Desa Kedak Kecamatan Semen Kabupaten Kediri sebesar 75\% dengan kategori Baik. Partisipasi ibu dalam pelaksanaan penimbangan balita di posyandu Desa Kedak Kecamatan Semen Kabupaten Kediri, dengan 3 kategori partisipasi kurang, partisipasi cukup, dan partisipasi yang terbanyak baik sebesar $53,6 \%$. Ada pengaruh pengetahuan ibu terhadap partisipasi ibu dalam pelaksanaan penimbangan balita di posyandu Desa Kedak Kecamatan Semen Kabupaten Kediri. Ada pengaruh pekerjaan ibu terhadap partisipasi ibu dalam pelaksanaan penimbangan balita di posyandu Desa Kedak Kecamatan Semen Kabupaten Kediri. Ada pengaruh kinerja kader posyandu terhadap partsipasi ibu dalam pelaksanaan penimbangan balita di posyandu di Desa Kedak Kecamatan Semen Kabupaten Kediri. dan Ada pengaruh kinerja kader posyandu terhadap partsipasi ibu dalam mengajak ibu-ibu melaksanakan penimbangan balita di posyandu Desa Kedak Kecamatan Semen Kabupaten Kediri.

\section{SARAN}

Peningkatan kinerja kader posyandu dalam menginformasi-kan jadwal posyandu 1 minggu sebelum tanggal kegiatan, misalnya ketika kegiatan pengajian rutin. Peningkatan partisipasi ibu dalam posyandu melalui kegiatan rutin di lingkungan desa. Menambah wawasan dan informasi tentang pentingnya posyandu dalam upaya meningkatkan partisipasi ibu untuk berkunjung ke posyandu sehingga dapat memantau tumbuh dan kembang balitanya setiap bulan melalui penimbangan balita di posyandu. Penyuluhan kepada masyarakat khususnya pada ibu yang bekerja sehingga angka kunjungan ibu balita ke posyandu semakin meningkat. Perlunya peninjauan kinerja kader secara berkala oleh bidan desa setiap bulan. Untuk Puskesmas Semen dan Dinas Kesehatan Kabupaten Kediri diharapkan dapat menjadi masukan dan dapat dijadikan bahan penyuluhan kepada masyarakat khususnya pada ibu yang bekerja sehingga kunjungannya ibu balita ke posyandu semakin meningkat.

\section{DAFTAR PUSTAKA}

Balitbang Kemenkes RI. 2013. Riset Kesehatan Dasar, RISKESDAS. Jakarta: Balitbang Kemenkes RI.

Dinas Kesehatan Kabupaten Kediri, 2013. Data Gizi Kurang dan Gizi Buruk. Kediri: Dinkes. Dinas Kesehatan Kabupaten Kediri, 2015. Data Gizi Kurang dan Gizi Buruk. Kediri: Dinkes. Kementerian Kesehatan RI. 2011. Pedoman Umum Pengelolaan Posyandu. Jakarta: Kementerian Kesehatan RI.

Notoatmodjo, Soekidjo. 2012. Metodologi Penelitian kesehatan. Jakarta: Rineka Cipta.

Pramono, S. 2012. Hubungan Pengetahuan Ibu dan Dukungan Keluaraga Degan Perilaku Kunjungan Ibu Anak Balita Ke Posyandu. Vol III No.4 Hal 144-199

Puskesmas Semen. 2015. Data Kader Posyandu. Kediri: Puskesmas.

Puskemas Semen. 2015. Data SKDN balita yang absen di posyandu Kedak.

Sasmito, Adi. 2010. Sistem Kesehatan. Jakarta: PT Raja Grafindo Persada.

Soeryoto. (2001). Hubungan Faktor Karakteristik Ibu Balita dengan Cakupan Penimbangan Balita di Kecamatan IV Jurai Kabupaten Pesisir Selatan Tahun 2000. Tesis, Fakultas

Kesehatan Masyarakat Universitas Indonesia, Jakarta 